\title{
FIRST RECORD OF Anselmella malacia Xiao \& Huang, 2006 (Hymenoptera: Eulophidae), A NEW INSECT PEST OF WATER APPLE (Syzygium samarangense) AND ITS ASSOCIATED PARASITOID IN DONG THAP PROVINCE, VIETNAM
}

\author{
Nguyen Thi Oanh ${ }^{1}$, Nguyen Kim Bup ${ }^{1}$, Khuat Dang Long, \\ ${ }^{1}$ Dong Thap University, Cao Lanh city, Dong Thap, Vietnam \\ ${ }^{2}$ Instititute of Ecology and Biological Resources, VAST, Ha Noi, Vietnam
}

Received 8 September 2019, accepted 10 December 2019

\begin{abstract}
The eulophid wasp, Anselmella malacia Xiao \& Huang, 2006 (Hymenoptera: Eulophidae), is reared from fruits of the water apple, Syzygium samarangense, and is reported as an important phytophagous developing as seed-eaters of Syzygium species in Malaysia. Analysing specimens of pest insects infested inside of pear-shaped fruits of the cultivated water apple, $S$. samarangense, in Dong Thap Province, South Vietnam, a total of four insect species were recorded as the important pests for fruits of six varieties of the cultivated water apples. The hymenoteran wasp, A. malacia, is recorded for the first time from Vietnam. Further evidence is needed to prove $A$. malacia being an invasive pest in Vietnam. The associated hymenopteran parasitoid assemblage with the fruit infested insect pests is also provided.
\end{abstract}

Keywords: Eulophidae, Anselmella, new pest, new record, parasitoid, phytophagous insects, Vietnam.

Citation: Nguyen Thi Oanh, Nguyen Kim Bup, Khuat Dang Long, 2019. First record of Anselmella malacia Xiao \& Huang, 2006 (Hymenoptera: Eulophidae), a new insect pest of water apple (Syzygium samarangense) and its associated parasitoid in Dong Thap Province, Vietnam. Academia Journal of Biology, 41(4): 7-14. https://doi.org/10.15625/2615-9023/v41n4.14673.

Corresponding author email: khuatdanglong@gmail.com

C2019 Vietnam Academy of Science and Technology (VAST) 


\section{INTRODUCTION}

Syzygium samarangense Merr. \& Perry. (Myrtaceae), commonly known as wax apple, wax jambu, water apple, rose apple or Java apple, has pear-shaped fruits and is common in Cambodia, Laos, Thailand, Taiwan and Vietnam, and is also frequently cultivated in India, Pembe (Tanzania) and Zanzibar (Xiao \& Huang, 2006). The water apple is growing in the most provinces in the southern Vietnam. The pear-shaped fruits are often juicy, with a subtle sweet taste somewhat resembling a common apple, and especially, this crop is considered as one of the special precious fruits of Dong Thap Province.

Recently, during several surveys conducted in late March 2019 for revealing parasitoids of fruit flies Bactrocera spp. infested the water apple, we recognized a community of hymenopteran wasps inside of the fruits of cultivated water apple in several areas of Dong Thap Province. Among hymenopteran wasp adults, we recorded the eulophid wasp, Anselmella malacia Xiao \& Huang, which causes a heavy damage to the cultivated water apples in Cao Lanh City and its vicinity.

\section{MATERIALS AND METHODS}

All the specimens examined in this study were collected from water apple fruits in Cao Lanh City, Dong Thap Province, in late March 2019. Since it is rather difficult to obtain reliable estimates of abundance of species inside the cavity of water apple fruits, the relative abundance data are collected by complete enumeration, counting all individuals found in well-defined demaging fruits, then the comparative abundunce of insect pests are expressed in percentage.

Identification of pest insects and their associated parasitoids is based on the following literatures: Doganlar \& Hassan (2010), Han et al. (2017), Leblanc et al. (2018), Li et al. (2013), Xiao et al. (2006), Yang et al. (2014). Anselmella malacia was identified by the comparison of the morphological characters of the pest population collected from six verieties of the cultivated water apples in Cao Lanh, Dong Thap, with the original description of Xiao et al. (2006). Measurements of A. malacia adults were made using a binocular microscope (DK3000; Meiji Techno Co., Ltd., Saitama, Japan).

All the research specimens are deposited in the Institute of Ecology and Biological Resources (Ha Noi, Vietnam) and Dong Thap University (Cao Lanh, Dong Thap, Vietnam).

\section{RESULTS}

\section{Pest insects associated with the fruit of cultivated water apple, Syzygium samarangense}

Of the most commonly sampled species, one was a seed-eater of Syzygium varieties: Anselmella malacia Xiao \& Huang (Hymenoptera, Eulophidae), and three others were frugivorous insects, Bactrocera dorsalis (Diptera, Tephritiidae); Orgyia postica (Walker) (Lepidoptera, Erebidae); and Cydia sp. (Lepidoptera, Tortricidae) (Table 1).

The seed-eater $A$. malacia and frugivore $B$. dorsalis were found as the most abundant species in the samples (> 50\%). Especially, in the fruits of two varieties Hong Dao Da and Hoa An planted in Dong Thap Province, up to $100 \%$ of the sampled specimens were of the seed-eater A. malacia.

Seeds attacked by the seed-eater A. malacia contained cavities and frass made by larvae and were often galled with a mass of pale conductive tissue and parenchyma, rather than green cotyledons (Fig 1). The effect of the seed-eater and other frugivorous insects on the viability of the seed in samples was not quantified. Nevertheless, seedlings were able to germinate from the most severely damaged fruits and seeds by the end of the trial.

Of total five insect species recorded from six varieties of the cultivated Syzygium samarangense in Cao Lanh city, Dong Thap Province, in addition to A. malacia, we have found another hymenopteran species, Megastigmus sp. and two lepidopteran 
species, Orgyia postica and Cydia sp. Orgyia postica was reported as the restrictively distributed fugivore in Vietnam (Waterhouse, 1993; CABI, 2019). Another frugivorous insect, Cydia sp. is also an abundant pest, i.e. $25-50 \%$ of the sampled specimens of the pest complex infested the water apple in Dong Thap Province.

Table 1. Assemblage of pest insects found in fruits of S. samarangense in Cao Lanh City and its vicinity

\begin{tabular}{|c|c|c|c|c|c|c|}
\hline \multirow[b]{2}{*}{ Pest species } & \multicolumn{6}{|c|}{ Local varieties of Syzygium } \\
\hline & $\begin{array}{l}\text { Xanh } \\
\text { Duong }\end{array}$ & $\begin{array}{l}\text { Hong } \\
\text { Dao Da }\end{array}$ & Sua & $\begin{array}{c}\text { An } \\
\text { Phuoc }\end{array}$ & Hoa An & Indian \\
\hline \multicolumn{7}{|l|}{ Diptera, Tephritiidae } \\
\hline $\begin{array}{l}\text { Bactrocera dorsalis (Hendel, } \\
\text { 1912) (oriental fruit fly) }\end{array}$ & $>50 \%$ & $>50 \%$ & $>50 \%$ & $<25 \%$ & $>50 \%$ & $<25 \%$ \\
\hline \multicolumn{7}{|l|}{ Hymenoptera, Eulophidae } \\
\hline $\begin{array}{l}\text { Anselmella malacia Xiao \& } \\
\text { Huang, } 2006\end{array}$ & $25-50 \%$ & $>50 \%$ & $25-50 \%$ & $<25 \%$ & $>50 \%$ & - \\
\hline \multicolumn{7}{|l|}{ Torimidae } \\
\hline \multicolumn{7}{|l|}{ Megastigmus sp. } \\
\hline \multicolumn{7}{|l|}{ Lepidoptera } \\
\hline \multicolumn{7}{|l|}{ Erebidae } \\
\hline $\begin{array}{l}\text { Orgyia postica (Walker, } \\
1955) \text { (cocoa tussock moth) }\end{array}$ & $<25 \%$ & $25-50 \%$ & $<25 \%$ & $<25 \%$ & $25-50 \%$ & - \\
\hline \multicolumn{7}{|l|}{ Tortricidae } \\
\hline Cydia sp. & $<25 \%$ & $25-50 \%$ & - & - & $25-50 \%$ & - \\
\hline
\end{tabular}

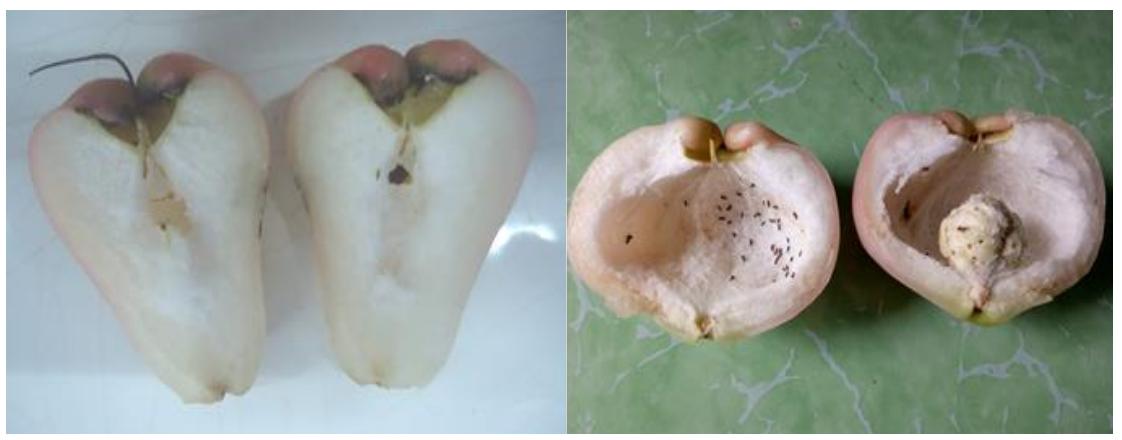

Figure 1. Healthy water apple fruit (left) and the fruit damaged by Anselmella malacia (right)
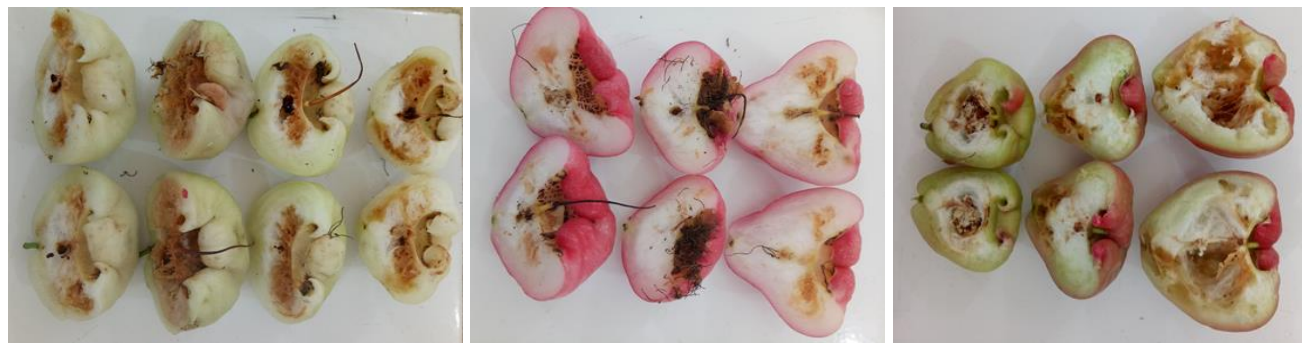

Figure 2. Damages inside of water apple fruits caused by Bactrocera dorsalis Xanh Duong variety (left), Hong Dao Da variety (middle) and Indian variety (right) 
Morphology of A. malacia collected from the water apple in Cao Lanh, Dong Thap

Based on the comparative characters of the wasp seed-eater infested Syzygium samarangense in Cao Lanh city, Dong Thap Province, it is possible to confirm this pest is Anselmella malacia Xiao \& Huang rather than Anselmella miltoni Girault (table 2).

Table 2. Comparative characters of Anselmella malacia Xiao \& Hoang, 2006

\begin{tabular}{|l|c|c|}
\hline \multicolumn{1}{|c|}{ Characters } & $\begin{array}{c}\text { Anselmella malacia } \\
\text { (Original } \\
\text { description) }\end{array}$ & $\begin{array}{c}\text { Anselmella malacia } \\
\text { (from Dong Thap, } \\
\text { Vietnam, } \mathrm{n}=30 \text { ) }\end{array}$ \\
\hline Eye height : Malar space & $2.6 \times$ & $2.80 \pm 0.18$ \\
\hline Head width : Head height (frontal view) & $1.3 \times$ & $1.30 \pm 0.04$ \\
\hline Head width : Head length (dorsal view) & $1.95 \times$ & $2.04 \pm 0.15$ \\
\hline Head width : Mouth width & $2.4 \times$ & $2.40 \pm 0.09$ \\
\hline Eye height : Eye length & $1.2 \times$ & $1.18 \pm 0.06$ \\
\hline POL : OOL & $2.9 \times$ & $2.70 \pm 0.32$ \\
\hline Eye length : Temple (dorsal view) & $20.0 \times$ & $19.55 \pm 1.06$ \\
\hline Scapus length : maximum width & $1.9 \times$ & $1.87 \pm 0.23$ \\
\hline MV : PMV & $2.3 \times$ & $2.18 \pm 0.31$ \\
\hline PMV : STV & $0.2 \times$ & $0.25 \pm 0.03$ \\
\hline Metasoma length : width & $1.5 \times$ & $1.50 \pm 0.18$ \\
\hline Body length (female) & $2.2 \mathrm{~mm}$ & $2.54 \pm 0.16 \mathrm{~mm}$ \\
\hline Body length (male) & $1.5-2.0 \mathrm{~mm}$ & $1.74 \pm 0.38 \mathrm{~mm}$ \\
\hline
\end{tabular}

Notes: $\mathrm{MV}=$ Marginal vein; PMV = Postmarginal vein; SMV = Submarginal vein; STV = Stigmal vein.

Preliminary biological characteristics of $A$. Malacia

Emerged adults were separated into males and females, and pairs of males and females were observed separately. While sucking flower nectar, A. malacia females prefer laying their eggs inside the most soft tissue of flower style during the anthesis stage of fruit phenology of $S$. samarangense (Fig. 3A), where eggs were laid as the clusters (Fig. 3B) or masses (Fig. 3C) and were white or creamy white, oval in shape (Figs. 3B-3C).
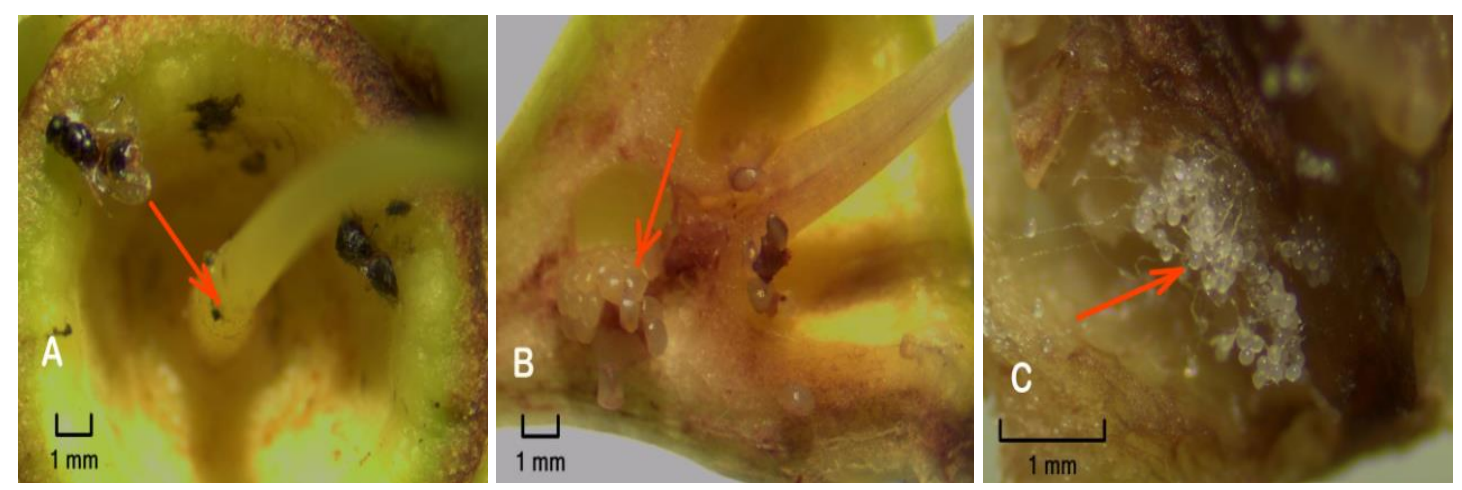

Figure 3. A = Hole made by A. malacia female on flower style; $\mathrm{B}$ and $\mathrm{C}=$ Clusters/masses of eggs inside of flower ovaries

The egg stage of $A$. malacia overlaps with the petal fall stage in $S$. samarangense.
Immature stage of A. malacia develops through a rapid stage to the middle fruit stage. 
Anselmella malacia enters into pupal stage and adults emerge, when the fruits of $S$. samarangense are in the mature stage.

After hatched from eggs inside the fruilets, larvae feed on the internal tissues of water apple fruits, larval and pupal stages lasts inside the fruits. Adults are emerged inside of the fruit cavity, where several holes are left (Figs. 4 A \& B).

In this study, another hymenopteran wasp, Megastigmus sp. (Hymenoptera;
Chalcidoidea: Torymidae), was found in the cavity of water apple fruits in Cao Lanh, Dong Thap (Fig. 5). In some published literatures (Roques et al., 1995; Roques et al., 2016), this wasp species was recorded and reported as a seed-feeding that emerged from seeds of wild rose, Rosa canina, in Ukraine. According to Doganlar \& Hassan (2010), Australian species of Megastigmus were recorded as pests associated with Eucalyptus plants.
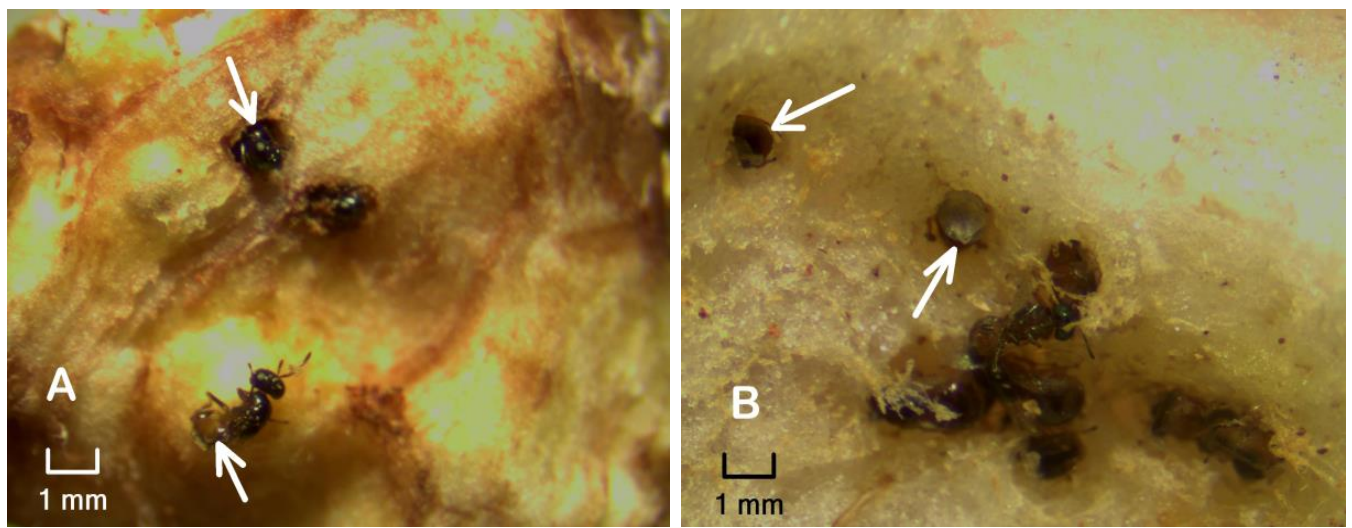

Figure 4. A \& B = Holes after A. malacia adults emerged outside of the fruit cavity

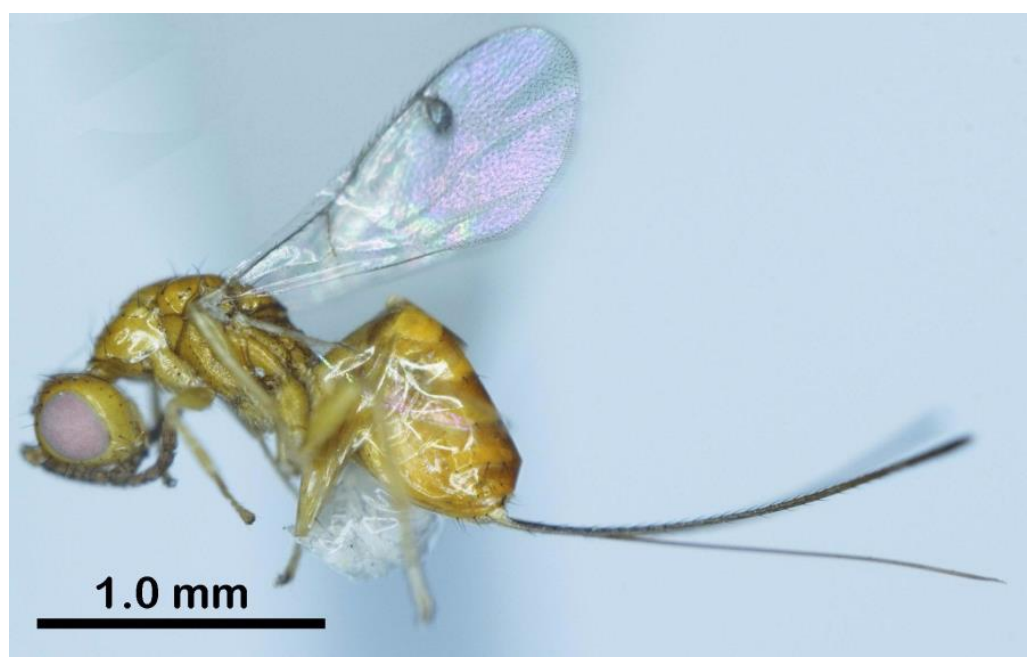

Figure 5. Megastigmus sp. (Habitus, female)

Hymenopteran parasitoid associated with the fruit infested insect pests

One dominant parasitic wasp, Aprostocetus sp. (Hymenoptera:
Chalcidoidea: Eulophidae) (Fig. 6), was surveyed and collected from water apple fruits in Cao Lanh City, Dong Thap Province, in March 2019, and this parasitoid is probably an 
egg parasitoid of A. malacia because the parasitic wasp was not directly reared from Anselmella malacia but parasitoid was incidentally captured inside of water apple fruits when the fruits were collected. However, two species of the genus
Aprostocetus, A. causalis La Salle \& Wu, from China and Thailand and A. felix La Salle, Yang \& Lin, from Taiwan, were reported as fortuitous parasitoids of invasive eulophid gall inducers (Tetrastichinae) on Eucalyptus and Erythrina (Yang et al., 2014).

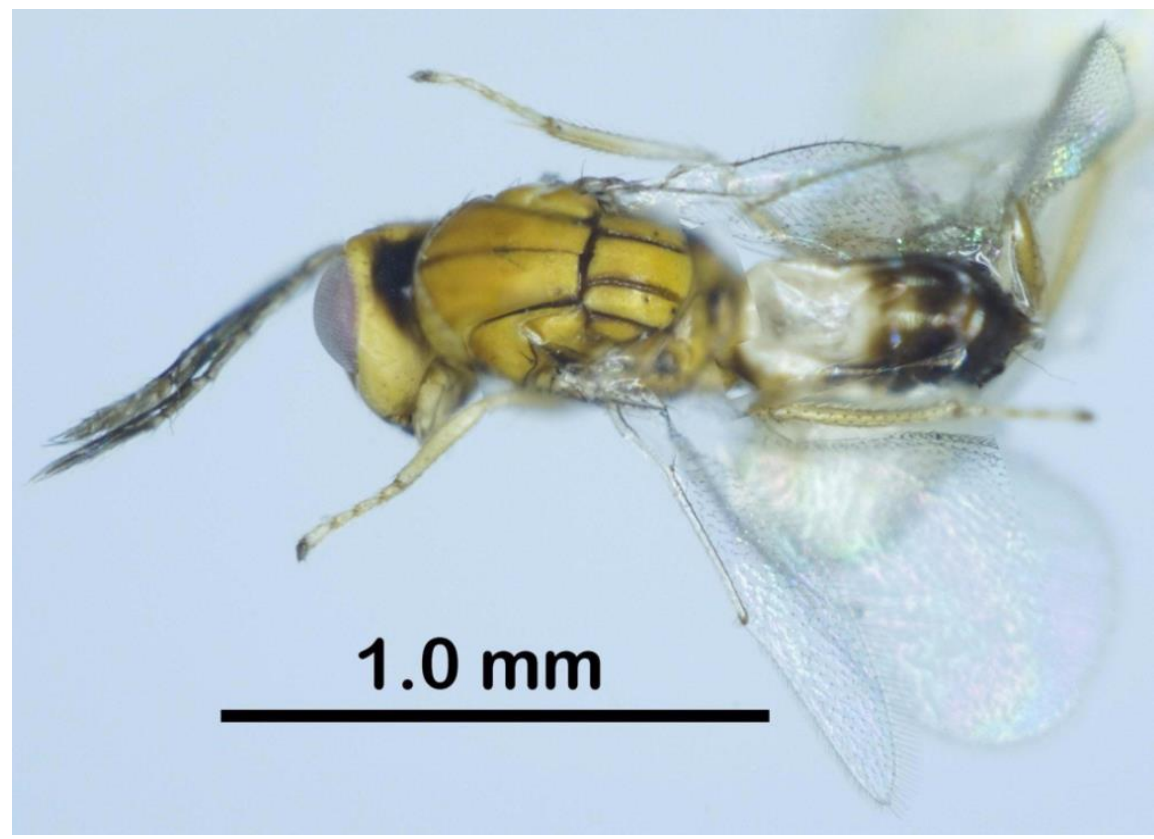

Figure 6. Aprostocetus sp. (Habitus, male)

\section{DISCUSSION}

Based on the comparative morphological characters of the eulophids collected from fruits of Syzygium samarangense in Cao Lanh city, Dong Thap, Anselmella malacia was revealed as one of few gall-inducing hymenopteran wasps living inside of fruits and this pest was recorded for the first time in Vietnam. Inducing galls within the seed chamber of the fruits of the water apple fruits, A. malacia has emerged as a serious problem for all the varieties of the cultivated $S$. samarangense in Cao Lanh City, Dong Thap Province.

Contrary to the frugivorous insect, Bactrocera dorsalis (Diptera: Tephritidae), which induces either an immature fruit drop or decay in pulp in the cultivated water apple, A. malacia should be considered as an issue of deep concern for the horticultural industry not only in Dong Thap Province, but all over Vietnam. Since there is not any practice applied for the control of $A$. malacia up to know, control measures should be introduced in the studied area as soon as possible.

\section{REFERENCES}

CAB International, 2019. Available from: https://www.cabi.org/isc/datasheet/37808\# todistributionTable (accessed 16 November 2019).

Doganlar M., Hassan E., 2010. Review of Australian Species of Megastigmus (Hymenoptera: Torymidae) Associated with Eucalyptus, with Descriptions of New Species. Australian Journal of Basic and Applied Sciences, 4(10): 5059-5120.

Han H. Y., Choi D. S., Ro K. E., 2017. Taxonomy of Korean Bactrocera (Diptera: Tephritidae: Dacinae) with review of their 
biology. Journal of Asia-Pacific Entomology, 20: 1321-1332.

Juniper P. A., David R Britton D. R., 2010. Insects associated with the fruit of Syzygium paniculatum (Magenta Lillypilly) and Syzygium australe (Brush Cherry). Australian Journal of Entomology, 49(4): 296-303. https://doi.org/10.1111/j.14406055.2010.00767.x

Kapoor V. C., 2005. Taxonomy and Biology of Economically Important Fruit Flies of India. Isr. J. Entomol., 35(36): 459-475.

Leblanc L., Doorenweerd C., Jose M. S., Pham H. T., Rubinoff D., 2018. Descriptions of four new species of Bactrocera and new country records highlight the high biodiversity of fruit flies in Vietnam (Diptera, Tephritidae, Dacinae). ZooKeys, 797: 87-115. https://doi.org/10.3897/ zookeys.797.29138

Le Duc Khanh, Nguyen Thi Thanh Hien, Tran Thanh Toan, Vu Thi Thuy Trang, Le Quang Khai, Vu Van Thanh, Dang Dinh Thang, Nguyen Thi Thuy Hang, 2010. Thanh phan ruoi hai qua ho Tephretidae va ky chu cua chung tai mot so vung sinh thai nong nghiep Vietnam. Tap chi Bao ve thuc vat, no. 3: 10-14 (in Vietnamese with English sumary).

Leung W. T. W., Butrum R. R., Chang F. H., Rao M. N., Polacchi W., 1972. Food composition table for use in East Asia. FAO, Rome, 347 pp.

Li X-Y., Achterberg C. van, Tan J-C., 2013. Revision of the subfamily Opiinae (Hymenoptera, Braconidae) from Hunan (China), including thirty-six new species and two new genera. ZooKeys, 268: 1168. https://doi.org/10.3897/zookeys. 268.407

Lim T. K., 2012. Edible Medicinal And NonMedicinal Plants: Volume 3, Fruits. Springer Science \& Business Media B. V., pp. 778-786.

Lin Y-C., Liao Y-C., Yang M-M., 2019. Biology of a Gall-inducing Species of
Anselmella (Hymenoptera:Eulophidae) within the Fruits of Syzygium samarangense (Myrtaceae). Formosan Entomol., 38(Special Issue): 56-68.

Roques A., Sun J-H, Pan Y-Zh, Zhang X-D, 1995. Contribution to the knowledge of seed chalcids, Megastigmus spp. (Hymenoptera: Torymidae), in China, with the description of three new species. Journal of the Swiss Entomological Society, 68(1-2): 211-223. https://doi.org/ $10.5169 /$ seals-402594

Roques A., Copeland R. S., Soldati L., Denux O., Auger-Rozenberg M. A., 2016. Megastigmus seed chalcids (Hymenoptera, Torymidae) radiated much more on Angiosperms than previously considered. I- Description of 8 new species from Kenya, with a key to the females of Eastern and Southern Africa. ZooKeys, 585: 51-124. https://doi.org/ 10.3897/zookeys.585.7503

Rosnah S., Wong W. K., Noraziah M. and Osman H., 2012. Chemical composition changes of two water apple (Syzygium samaragense). International Food Research Journal, 19(1): 167-174.

Shu Z. H., Meon R., Tirtawinata, Thanarut C. 2006. Wax apple production in selected tropical Asian countries, ISHS, Acta Hort, (ISHS), 773: 161-164.

Turgeon J. J., Kamijo K., DeBarr G., 1997. A new species of Megastigmus Dalman (Hymenoptera: Torymidae) reared from seeds of Atlantic white cedar (Cupressaceae), with notes on infestation rates. Proceedings of the Entomological Society of Washington, 99(4): 608-613.

Wharton R. A., 1997. Generic relationships of opiine Braconidae (Hymenoptera) parasitic in fruit-infesteing Tephritidae (Diptera). Contributions of the Americal Entomological Instite, 30(3): 1-53.

Waterhouse D. F., 1993. The Major Arthropod Pests and Weeds of Agriculture in Southeast Asia. ACIAR Monograph 
No. 21. Canberra, Australia: Australian Centre for International Agricultural Research, $141 \mathrm{pp}$.

Xiao H., Xu L-N., Huang D-W., Zhao Z-Y., 2006. Anselmella malacia, A New Pest Wasp (Hymenoptera: Chalcidoidea: Eulophidae) reared from Syzygium samarangense in Malaysia. Phytoparasitica, 34(3): 261-264.
Yang M-M., Lin Y-C., Wu Y., Fisher N., Saimanee T., Sangtongpraow B., Zhu C., Chiu W. C.-H. and Salle J. L., 2014. Two new Aprostocetus species (Hymenoptera: Eulophidae: Tetrastichinae), fortuitous parasitoids of invasive eulophid gall inducers (Tetrastichinae) on Eucalyptus and Erythrina. Zootaxa, 3846(2): 261-272. https://doi.org/10.11646/zootaxa.3846.2.6 